\title{
Sinergisme Ekstrak Piper aduncum dan Tephrosia vogelii terhadap Penggerek Batang Padi Kuning, Scirpophaga incertulas
}

\author{
Muhammad Sigit Susanto dan Djoko Prijono \\ Departemen Proteksi Tanaman, Fakultas Pertanian \\ Institut Pertanian Bogor, Kampus IPB Dramaga, Bogor 16680 \\ E-mail: djokopr@ipb.ac.id
}

\section{Abstract \\ Synergism of Piper aduncum and Tephrosia vogelii Extracts against the Rice Yellow Stem Borer, Scirpophaga incertulas}

Rice (Oryza sativa) is one of the important staple food crops in the world. One of the important pests on rice is the rice yellow stem borer (RYSB) Scirpophaga incertulas. One of the alternative control techniques that can be applied is by using botanical insecticides. The purpose of this study was to determine the synergism between Piper aduncum fruit and Tephrosia vogelii leaf extracts against RYSB larvae. $P$. aduncum and $T$. vogelii extracts, either tested separately or in mixtures with concentration ratios of 1:1, 2:1, and 1:2, were effective against RYSB larvae. The treatments with these extracts caused death in YRSB larvae at 72 hours after treatment in which the affected larvae showed internal tissue damage symptom. The most toxic test material to RYSB larvae was $P$. aduncum and $T$. vogelii extract mixture with a concentration ratio of 1:2. LC50 and LC95 of $P$. aduncum extract were $0.175 \%$ and $0.126 \%$, respectively, while those of $T$. vogelii extract were $1.620 \%$ and $2.075 \%$, respectively. $P$. aduncum and $T$. vogelii extract mixture with $1: 1$ ratio had LC50 $0.056 \%$ and LC $95.143 \%$, while that with 2:1 ratio had LC $50.025 \%$ and LC95 $0.149 \%$. LC50 and LC95 of the mixture with $1: 2$ ratio were $0.016 \%$ and $0.083 \%$, respectively. $P$. aduncum and $T$. vogelii extract mixture at the three concentration ratios were more effective than $P$. aduncum and $T$. vogelii extracts applied separately and synergistic to RYSB larvae.

Keywords: Botanical Insecticide, Piper aduncum, Scirpophaga incertulas, Synergism, Tephrosia vogelii.

\begin{abstract}
Abstrak
Padi (Oryza sativa) merupakan salah satu komoditas penting pangan dunia. Salah satu hama penting pada tanaman padi adalah penggerek batang padi kuning, Scirpophaga incertulas. Salah satu cara pengendalian yang dapat diterapkan adalah dengan menggunakan insektisida nabati. Tujuan penelitian ini adalah menentukan sinergisme ekstrak buah Piper aduncum dan daun Tephrosia vogelii terhadap larva $S$. incertulas. Perlakuan ekstrak $P$. aduncum dan $T$. vogelii baik secara terpisah maupun campuran pada nisbah konsentrasi 1:1, 2:1, dan 1:2 efektif terhadap larva $S$. incertulas. Perlakuan ini dapat menimbulkan kematian pada $S$. incertulas dengan gejala kerusakan jaringan larva instar 1 pada 72 jam setelah perlakuan. Bahan uji yang paling beracun terhadap larva $S$. incertulas adalah campuran ekstrak $P$. aduncum dan $T$. vogelii dengan nisbah konsentrasi 1:2. LC50 dan LC95 ekstrak $P$. aduncum masing-masing $0,175 \%$ dan $0,126 \%$. Sementara itu LC50 dan LC95 ekstrak $T$. vogelii masing-masing 1,620\% dan 2,075\%. Campuran ekstrak $P$. aduncum dan $T$. vogelii pada nisbah konsentrasi 1:1 memiliki $\mathrm{LC}_{50} 0,056 \%$ dan $\mathrm{LC}_{95}$ 0,143\%. Sementara itu campuran ekstrak tersebut pada nisbah konsentrasi 2:1 memiliki LC50 0,025\% dan LC95 0,149\%. LC50 dan LC95 campuran ekstrak tersebut pada nisbah konsentrasi $1: 2$ masing-masing 0,016\% dan 0,083\%. Campuran ekstrak $P$. aduncum dan $T$. vogelii pada ketiga nisbah konsentrasi lebih efektif dibandingkan dengan ekstrak tunggalnya dan bersifat sinergis terhadap larva $S$. incertulas.
\end{abstract}

Kata kunci: Insektisida Nabati, Piper aduncum, Tephrosia vogelii, Scirpophaga incertulas, Sinergisme. 


\section{PENDAHULUAN}

Padi (Oryza sativa L.) merupakan salah satu komoditas penting pangan dunia. Menurut data FAO (2013), Indonesia menempati urutan ketiga dalam penyediaan beras di dunia dan lebih dari 90\% penduduk Indonesia mengonsumsi beras sebagai bahan pangan pokoknya, yakni mencapai 33,56 juta ton atau $9,66 \%$ dari total penyediaan beras dunia. Sementara itu menurut hasil sensus penduduk pada tahun 2010 diketahui bahwa laju pertumbuhan penduduk Indonesia per tahun adalah 1,49\% (BPS, 2014). Berdasarkan data tersebut, total konsumsi domestik beras di Indonesia diperkirakan akan terus meningkat. Kondisi ini menjadi tantangan dalam pemenuhan kebutuhan pangan masyarakat Indonesia.

Hama merupakan salah satu faktor pembatas penting dalam usaha peningkatan produksi padi di Indonesia. Hama yang hingga saat ini menjadi masalah penting pada pertanaman padi di Indonesia adalah penggerek batang padi kuning (PBPK) Scirpophaga incertulas (Walker) (Lepidoptera: Crambidae) (Direktorat Perlindungan Tanaman Pangan, 2013). PBPK dapat menyerang semua fase tumbuh tanaman padi mulai fase pembibitan, fase anakan hingga fase pembungaan (Pathak \& Khan, 1994). Hama tersebut dapat menyebabkan kerugian ekonomi yang tinggi terutama di sentra-sentra produksi padi seperti daerah Pantura (Pantai Utara) Jawa Barat. PBPK umumnya lebih sering ditemukan daripada penggerek batang padi putih. Dominasi penggerek batang padi kuning atas penggerek batang padi putih mencapai $90 \%$ baik pada tanaman padi yang ditanam serempak maupun tidak serempak (BB Padi, 2012). Untuk itu, diperlukan suatu tindakan yang tepat untuk mengendalikan hama tersebut.

Saat ini tindakan yang sering dilakukan petani untuk mengendalikan hama penggerek batang padi adalah pengendalian kimia menggunakan insektisida sintetik karena cara-cara nonkimia sering tidak tersedia di tingkat petani. Penggunaan insektisida sintetik yang tidak bijaksana dapat menimbulkan dampak negatif termasuk terjadinya resistensi hama terhadap insektisida sehingga akhirnya populasi hama tidak dapat dikendalikan lagi dengan insektisida tersebut (Perry et al., 1998). Pengendalian hama dengan memanfaatkan potensi sumber daya hayati seperti insektisida nabati merupakan salah satu alternatif pengendalian yang dapat diterapkan (Prakash \& Rao, 1997).
Dua jenis tumbuhan yang saat ini sudah diketahui memiliki aktivitas insektisida ialah buah sirih hutan Piper aduncum (Piperaceae) dan daun kacang babi Tephrosia vogelii (Fabaceae). Syahroni dan Prijono (2013) melaporkan bahwa ekstrak etil asetat buah $P$. aduncum memiliki aktivitas insektisida yang kuat terhadap larva Crocilomia pavonana dengan $\mathrm{LC}_{95}$ 0,30\%. Sementara itu, Abizar dan Prijono (2010) melaporkan bahwa ekstrak etil asetat daun $T$. vogelii juga memiliki aktivitas insektisida yang kuat terhadap larva $C$. pavonana dengan LC95 $0,26 \%$. Selain digunakan secara tunggal, beberapa ekstrak tumbuhan juga dapat digunakan dalam bentuk campuran. Nailufar (2011) melaporkan bahwa campuran ekstrak $P$. aduncum dan $T$. vogelii pada tiga nisbah konsentrasi, yaitu 1:1, 1:5, dan 5:1, bersifat sinergistik kuat terhadap larva instar 2 C. pavonana.

Ekstrak $P$. aduncum dan $T$. vogelii belum pernah diuji terhadap PBPK. Penelitian ini bertujuan menentukan sinergisme ekstrak $P$. aduncum dan $T$. vogelii terhadap larva PBPK di laboratorium. Hasil penelitian ini diharapkan dapat memberikan informasi tentang tingkat keefektifan ekstrak $P$. aduncum dan $T$. vogelii serta campuran kedua ekstrak tersebut sebagai alternatif pengendalian yang efektif dan ramah lingkungan terhadap PBPK.

\section{BAHAN DAN METODE}

Penelitian dilaksanakan di Laboratorium Fisiologi dan Toksikologi Serangga, Departemen Proteksi Tanaman, Fakultas Pertanian, Institut Pertanian Bogor (IPB), dari April 2013 sampai Februari 2014.

\section{Persiapan Tanaman Padi}

Padi cv. Ciherang yang digunakan untuk pengujian berumur 40-50 hari setelah tanam (HST) dan berasal dari hasil perbanyakan di rumah kaca kebun percobaan IPB Dramaga, Bogor. Bagian tanaman padi yang digunakan adalah pangkal batang yang dipotong dengan panjang 4 $\mathrm{cm}$.

\section{Persiapan Serangga Uji}

Kelompok telur $S$. incertulas diambil dari lahan petani di desa Tegal Sawah, Kecamatan Karawang Timur, Kabupaten Karawang, kemudian dibawa ke laboratorium dan dirawat hingga menetas. Setelah telur menetas, larva dipindahkan ke batang padi muda sebagai tempat hidup dan 
makanan sementara selama 24 jam. Larva instar 1 yang berumur 24 jam setelah menetas digunakan untuk pengujian.

\section{Ekstraksi Bahan Tumbuhan}

Insektisida nabati yang digunakan untuk pengujian adalah ekstrak buah $P$. aduncum dan daun $T$. vogelii. Buah $P$. aduncum diperoleh dari hutan sekitar kampus IPB Dramaga Bogor, sedangkan daun $T$. vogelii berasal dari Kawasan Agropolitan, Kecamatan Pacet, Kabupaten Cianjur.

Buah $P$. aduncum dan daun $T$. vogelii dipotong kecil-kecil lalu dikeringanginkan. Setiap bahan tumbuhan digiling menggunakan blender hingga menjadi serbuk, kemudian diayak menggunakan pengayak kawat kasa berjalinan 0,5 mm. Serbuk tumbuhan tersebut masing-masing sebanyak $200 \mathrm{~g}$ direndam dalam etil asetat dengan perbandingan 1:8 (w/v). Perendaman diulang sebanyak tiga kali (Nailufar, 2011). Rendaman tersebut diaduk dan dibiarkan selama sekurangkurangnya 24 jam. Cairan hasil rendaman disaring menggunakan corong kaca yang dialasi kertas saring Whatman No. 41 diameter $185 \mathrm{~mm}$ dan ditampung dalam labu penguap. Hasil saringan diuapkan dengan menggunakan rotary evaporator pada suhu $50 \stackrel{\circ}{\circ}$ dan tekanan 240 mbar sehingga diperoleh ekstrak kasar. Setiap ekstrak yang diperoleh disimpan dalam lemari pendingin pada suhu $\pm 4{ }^{\circ} \mathrm{C}$ hingga saat digunakan untuk pengujian.

\section{MetodePengujian}

\section{Uji Toksisitas Ekstrak Tunggal}

Ekstrak $P$. aduncum dan T. vogelii masingmasing diuji pada enam taraf konsentrasi yang diharapkan dapat mengakibatkan kematian serangga uji antara 15\% dan 95\%, yang ditentukan berdasarkan uji pendahuluan. Taraf konsentrasi ekstrak $P$. aduncum yang diuji ialah $0,10 \%, 0,23 \%$, $0,36 \%, 0,49 \%, 0,62 \%$, dan $0,75 \%$, sementara ekstrak $T$. vogelii diuji pada taraf konsentrasi 0,08\%, 0,20\%, 0,30\%, 0,40\%, 0,50\%, dan 0,60\%. Pengujian dilakukan dengan menggunakan metode celup batang padi. Setiap ekstrak dicampur dengan pelarut metanol dan pengemulsi Tween 80 dengan perbandingan 5:1 (v/v) [konsentrasi akhir

$$
I K=\frac{L C x^{1(\mathrm{~cm})}}{L C x^{1}}+\frac{L C x^{2(\mathrm{~cm})}}{L C x^{2}}+\left[\frac{L C x^{1(\mathrm{~cm})}}{L C x^{1}} x \frac{L C x^{2(\mathrm{~cm})}}{L C x^{2}}\right]
$$

LCx1 dan LCx2 masing-masing LCx ekstrak $P$. aduncum dan ekstrak $T$. vogelii yang diujikan pada
1,2\%], kemudian ditambahkan akuades sehingga didapatkan suspensi dengan konsentrasi yang diinginkan. Semua suspensi ekstrak dikocok dengan menggunakan pengocok ultrasonik untuk mencampurkan secara merata ekstrak tersebut di dalam air. Sebagai larutan kontrol digunakan akuades yang hanya mengandung pelarut metanol dan pengemulsi Tween 80 5:1 (v/v) dengan konsentrasi 1,2\% (Abizar \& Prijono, 2010).

Potongan batang padi berukuran $4 \mathrm{~cm}$ dicelupkan dalam suspensi ekstrak dengan konsentrasi tertentu sampai basah merata, kemudian dikeringanginkan di atas kertas stensil. Potongan batang padi kontrol dicelup dalam larutan kontrol. Setiap potong batang padi perlakuan dan batang padi kontrol diletakkan secara terpisah dalam nampan plastik 16-sel kemudian ke dalam setiap sel dimasukkan satu larva instar $1 S$. incertulas. Nampan plastik tersebut selanjutnya ditutup rapat agar larva uji tidak keluar. Untuk setiap perlakuan digunakan 40 larva. Larva dibiarkan makan selama 72 jam. Jumlah larva yang mati dicatat pada 72 jam setelah perlakuan (JSP). Data mortalitas serangga uji diolah dengan analisis probit menggunakan program POLO-PC (LeOra Software, 1987)

\section{Uji Toksisitas Ekstrak Campuran}

Ekstrak $P$. aduncum dan $T$. vogelii juga diuji dalam bentuk campuran pada nisbah konsentrasi 1:1, 2:1, dan 1:2 (w/w) dengan enam taraf konsentrasi yang ditentukan berdasarkan hasil pengujian toksisitas ekstrak tunggal di atas. Enam taraf konsentrasi yang diuji ialah 0,020\%, 0,035\%, 0,055\%, 0,075\%, 0,105\%, dan 0,140\%. Cara pengujian dan waktu pengamatan pada uji ekstrak campuran sama seperti pada uji toksisitas ekstrak tunggal. Data mortalitas 72 JSP diolah dengan analisis probit menggunakan program POLO-PC seperti di atas.

Sifat aktivitas campuran ekstrak $P$. aduncum dan $T$. vogelii dianalisis dengan menghitung indeks kombinasi pada taraf LC50 dan LC95. Indeks kombinasi (IK) pada taraf LCx tersebut dihitung dengan rumus berikut (Chou \& Talalay, 1984): pengujian terpisah; LCx1 (cm) dan LCx2 (cm) masing-masing LCx ekstrak $T$. vogelii dan ekstrak 
$P$ aduncum yang dalam campuran yang mengakibatkan mortalitas $\mathrm{x}$ (misal 50\% dan 95\%). Nilai LCx tersebut diperoleh dengan cara mengalikan $\mathrm{LCx}(\mathrm{cm})$ campuran dengan proporsi konsentrasi ekstrak dalam campuran.

Kategori sifat interaksi campuran adalah sebagai berikut (diadaptasi dari Gisi, 1996):

a. bila IK $<0.5$, komponen campuran bersifat sinergistik kuat;

b. bila $0.5 \leq \mathrm{IK} \leq 0.77$, komponen campuran bersifat sinergistik lemah;

c. bila $0.77<\mathrm{IK} \leq 1.43$, komponen campuran bersifat aditif;

d. bila IK > 1.43, komponen campuran bersifat antagonistik.

\section{HASIL DAN PEMBAHASAN}

\section{Toksisitas Ekstrak Tunggal}

Secara umum, baik perlakuan dengan ekstrak $P$. aduncum maupun ekstrak $T$. vogelii pada keenam taraf konsentrasi dapat mematikan serangga uji antara 40\% dan 95\% (Tabel 1). Pada konsentrasi $0.10 \%$, perlakuan dengan ekstrak $P$. aduncum dapat mematikan serangga uji hingga 40\%. Perlakuan dengan ekstrak $P$. aduncum pada kisaran konsentrasi $\quad 0,23 \%-0,75 \%$ dapat mematikan serangga uji sebesar 62,5\%-90\%. Pada taraf konsentrasi $0,08 \%$, perlakuan dengan ekstrak T. vogelii sudah mengakibatkan kematian serangga uji sampai 50\%. Pada kisaran konsentrasi 0,20\%$0,60 \%$, perlakuan dengan ekstrak $T$. vogelii dapat mematikan serangga uji sebesar 60\%-95\%. Secara umum terlihat bahwa tingkat kematian serangga uji meningkat dengan makin tingginya konsentrasi ekstrak (Tabel 1). Perlakuan dengan ekstrak $P$. aduncum dan $T$. vogelii masing-masing pada konsentrasi $0,62 \%$ dan $0,60 \%$ dapat mematikan $80 \%$ serangga uji sehingga kedua ekstrak tersebut dipandang berpotensi baik untuk digunakan sebagai insektisida nabati. Dadang dan Prijono (2008) menyatakan bahwa insektisida nabati yang diekstrak dengan pelarut organik dikatakan memiliki potensi yang baik bila pada konsentrasi $\leq$ $1 \%$ sudah dapat mengakibatkan mortalitas serangga uji $\geq 80 \%$.

Berdasarkan hasil analisis probit diketahui bahwa LC50 dan LC95 ekstrak $P$. aduncum masingmasing $0,175 \%$ dan $1,620 \%$, sementara $\mathrm{LC}_{50}$ dan LC95 ekstrak $T$. vogelii masing-masing 0,126\% dan 2,075\% (Tabel 2). Data tersebut menunjukkan bahwa ekstrak $T$. vogelii lebih beracun 1,4 kali lipat dibandingkan dengan ekstrak $P$. aduncum pada taraf $\mathrm{LC}_{50}$, tetapi pada taraf $\mathrm{LC}_{95}$ ekstrak $P$. aduncum lebih beracun 1,3 kali lipat daripada ekstrak $T$. vogelii terhadap larva instar $1 S$. incertulas. Perbedaan toksisitas kedua ekstrak tersebut mungkin disebabkan oleh perbedaan kecepatan kerja senyawa aktifnya seiring dengan peningkatan konsentrasi ekstrak. Hal ini terlihat dari kemiringan garis regresi probit ekstrak $P$. aduncum yang lebih curam dibandingkan dengan ekstrak $T$. vogelii. Semakin curam kemiringan garis regresi berarti, penambahan konsentrasi yang sama akan meningkatkan kematian serangga uji dalam proporsi yang lebih tinggi dibandingkan dengan ekstrak yang memiliki garis regresi yang lebih landai.

Tabel 1. Pengaruh ekstrak tunggal $P$. aduncum dan $T$. vogelii terhadap mortalitas larva instar $1 S$. incertulas pada 72 jam setelah perlakuan.

\begin{tabular}{lcc}
\hline Jenis ekstrak & Konsentrasi $(\%, \mathrm{w} / \mathrm{v})$ & Persentase kematian larva \\
\hline Piper aduncum & Kontrol & 7,5 \\
& 0,10 & 40,0 \\
& 0,23 & 62,5 \\
& 0,36 & 70,0 \\
Tephrosia vogelii & 0,49 & 75,0 \\
& 0,62 & 85,0 \\
& 0,75 & 90,0 \\
& Kontrol & 7,5 \\
& 0,08 & 50,0 \\
& 0,20 & 60,0 \\
& 0,30 & 65,0 \\
& 0,40 & 72,5 \\
\end{tabular}


Tabel 2. Penduga parameter toksisitas dua jenis ekstrak terhadap larva instar $1 S$. incertulas pada 72 jam setelah perlakuan.

\begin{tabular}{lcccc}
\hline Jenis ekstrak & $a \pm \mathrm{GB}^{\mathrm{a}}$ & $b \pm \mathrm{GB}^{\mathrm{a}}$ & $\mathrm{LC} 50(\%)$ & LC95 $(\%)$ \\
\hline Piper aduncum & $1,288 \pm 0,182$ & $1,702 \pm 0,326$ & 0,175 & 1,620 \\
Tephrosia vogelii & $1,216 \pm 0,201$ & $1,353 \pm 0,320$ & 0,126 & 2,075 \\
\hline
\end{tabular}

a $a$ : intersep regresi probit. $b$ : kemiringan regresi probit. GB: galat baku.

\section{Toksisitas Ekstrak Campuran}

Seperti halnya pada perlakuan dengan ekstrak tunggal $P$. aduncum dan $T$. vogelii, perlakuan dengan campuran ekstrak $P$. aduncum dan ekstrak $T$. vogelii pada tiga nisbah konsentrasi mengakibatkan kematian larva $S$. incertulas yang makin meningkat dengan makin tingginya konsentrasi ekstrak campuran tersebut (Tabel 3).
Campuran ekstrak pada nisbah konsentrasi 1:1 dapat mematikan lebih dari 50\% serangga uji pada konsentrasi $0,075 \%$. Campuran ekstrak $P$. aduncum dan $T$. vogelii pada nisbah konsentrasi 2:1 dan 1:2 lebih efektif daripada campuran 1:1 karena pada taraf konsentrasi terendah, yaitu 0,020\%, campuran 2:1 dan 1:2 dapat mematikan lebih dari $50 \%$ serangga uji.

Tabel 3. Pengaruh campuran esktrak $P$. aduncum dan $T$. vogelii terhadap mortalitas larva instar $1 S$. incertulas pada 72 jam setelah perlakuan.

\begin{tabular}{lrcc}
\hline Konsentrasi & \multicolumn{3}{c}{ Kematian larva (\%) pada perlakuan campuran ekstrak dengan nisbah konsentrasi } \\
\cline { 2 - 4 } (\%, w) & $1: 1$ & $2: 1$ & $1: 2$ \\
\hline Kontrol & 7,5 & 7,5 & 5,0 \\
0,020 & 17,5 & 55,0 & 65,0 \\
0,035 & 27,5 & 62,5 & 75,0 \\
0,055 & 32,5 & 67,5 & 90,0 \\
0,075 & 87,5 & 80,0 & 92,5 \\
0,105 & 90,0 & 95,0 & 97,5 \\
0,140 & 92,5 & 100 & 100 \\
\hline
\end{tabular}

Campuran ekstrak 2:1 dan 1:2 dapat mematikan semua serangga uji pada konsentrasi tertinggi $(0,140 \%)$ (Tabel 3). Baik pada taraf LC50 maupun LC95, campuran ekstrak $P$. aduncum dan T. vogelii dengan nisbah konsentrasi 1:2 paling beracun dan paling sinergis terhadap larva $S$. incertulas, diikuti campuran dengan nisbah konsentrasi 2:1 dan campuran dengan nisbah konsentrasi 1:1. Sifat sinergistik campuran ekstrak $P$. aduncum dan $T$. vogelii kemungkinan disebabkan oleh komponen utama ekstrak $P$. aduncum yaitu dilapiol yang selain bersifat sebagai insektisida juga bersifat sebagai sinergis bagi insektisida nabati lain (Bernard et al., 1995; Scott et al., 2008).

Berdasarkan hasil analisis probit diketahui bahwa LC50 campuran ekstrak $P$. aduncum dan $T$. vogelii dengan nisbah konsentrasi 1:1, 2:1, dan 1:2 berturut-turut $0,056 \%, 0,025 \%$, dan $0,016 \%$, sementara nilai LC95-nya berturut-turut $0,143 \%$, 0,149\%, dan 0,083\% (Tabel 4). Data tersebut menunjukkan bahwa pada taraf LC50, campuran ekstrak $P$. aduncum dan $T$. vogelii pada ketiga nisbah konsentrasi lebih beracun 3,13-10,94 kali lipat dibandingkan dengan ekstrak tunggal $P$. aduncum dan lebih beracun 2,25-7,87 kali lipat dibandingkan dengan ekstrak tunggal $T$. vogelii. Berdasarkan data tersebut juga dketahui bahwa di antara ketiga nisbah konsentrasi, campuran ekstrak dengan nisbah konsentrasi 1:2 merupakan campuran ekstrak yang paling beracun terhadap larva $S$. incertulas. 
Tabel 4. Penduga parameter toksisitas campuran ekstrak $P$. aduncum dan $T$. vogelii pada tiga nisbah konsentrasi terhadap larva instar $1 S$. incertulas pada 72 jam setelah perlakuan.

\begin{tabular}{lcccc}
\hline $\begin{array}{l}\text { Nisbah } \\
\text { konsentrasi }\end{array}$ & $a \pm \mathrm{GB}^{\mathrm{a}}$ & $b_{ \pm} \mathrm{GB}^{\mathrm{a}}$ & $\mathrm{LC} 50(\%)$ & LC95 (\%) \\
\hline $1: 1$ & $5,043 \pm 0,705$ & $4,023 \pm 0,598$ & 0,056 & 0,143 \\
$2: 1$ & $3,409 \pm 0,505$ & $2,133 \pm 0,378$ & 0,025 & 0,149 \\
$1: 2$ & $4,132 \pm 0,624$ & $2,299 \pm 0,442$ & 0,016 & 0,083 \\
\hline
\end{tabular}

a $a$ : intersep regresi probit, $b$ : kemiringan regresi probit, GB: galat baku.

Berdasarkan hasil perhitungan indeks kombinasi pada taraf LC50, campuran ekstrak $P$. aduncum dan $T$. vogelii pada ketiga nisbah konsentrasi bersifat sinergistik kuat (Tabel 5). Indeks kombinasi terbaik terdapat pada campuran ekstrak $P$. aduncum dan $T$. vogelii dengan nisbah konsentrasi 1:2. Pada taraf LC95, campuran ekstrak yang paling baik sifat aktivitasnya juga campuran dengan nisbah 1:2 (sinergistik lemah), sedangkan pada nisbah lainnya campuran bersifat aditif. Selain itu, campuran ekstrak $P$. aduncum dan $T$. vogelii 1:2 juga paling beracun terhadap larva $S$. incertulas (LC50 dan LC95 paling rendah, Tabel 4) sehingga campuran tersebut paling berpotensi untuk dikembangkan lebih lanjut.

Tabel 5. Sifat aktivitas campuran ekstrak $P$. aduncum dan $T$. vogelii pada tiga nisbah konsentrasi terhadap larva instar $1 S$. incertulas pada 72 jam setelah perlakuan

\begin{tabular}{lccccc}
\hline \multirow{2}{*}{$\begin{array}{l}\text { Nisbah } \\
\text { konsentrasi }\end{array}$} & \multicolumn{2}{c}{ Indeks kombinasi } & & \multicolumn{2}{c}{ Sifat aktivitas campuran } \\
\cline { 2 - 3 } \cline { 5 - 6 } \cline { 5 - 6 } $1: 1$ & LC50 & LC95 & & LC50 & LC95 \\
$2: 1$ & 0,415 & 1,214 & & Sinergistik kuat & Aditif \\
$1: 2$ & 0,155 & 1,198 & & Sinergistik kuat & Aditif \\
\hline
\end{tabular}

Pencampuran ekstrak $P$. aduncum dan $T$. vogelii dalam penelitian ini dimaksudkan untuk mengetahui sifat aktivitas campuran kedua ekstrak jika diaplikasikan secara bersamaan. Selain itu pencampuran insektisida nabati biasanya dimaksudkan untuk meningkatkan keefektifan atau meningkatkan spektrum aktivitas insektisida nabati sehingga beberapa jenis hama dapat dikendalikan sekaligus. Pencampuran tersebut juga dapat mengatasi keterbatasan bahan baku insektisida nabati di tingkat petani karena tumbuhan sumber insektisida nabati tidak selalu terdapat melimpah di setiap daerah (Dadang dan Prijono, 2008).

Hasyim (2011) melaporkan bahwa komponen utama dalam fraksi aktif ekstrak buah $P$. aduncum adalah dilapiol. Senyawa tersebut mengandung gugus metilendioksifenil (MDF) yang merupakan ciri senyawa yang bekerja sebagai penghambat enzim polisubstrat monooksigenase (PSMO) (Metcalf, 1967; Perry et al., 1998). Enzim PSMO berperan menurunkan daya racun senyawa toksik di dalam sel dengan cara mengoksidasi berbagai jenis senyawa racun dari luar tubuh dan limbah metabolisme di dalam tubuh serangga, sehingga apabila aktivitasnya terganggu dapat menekan penguraian senyawa racun dalam tubuh serangga tersebut (Scott et al., 2008). Terhambatnya enzim PSMO dapat mengakibatkan penumpukan senyawa atau metabolit toksik di dalam tubuh serangga yang akhirnya dapat mengakibatkan kematian (Bernard et al., 1995). Dalam kaitannya dengan dampak sinergis, terhambatnya enzim penurun daya racun senyawa asing tersebut mengakibatkan senyawa aktif dalam ekstrak T. vogelii yang dicampurkan tidak terurai dan dapat tetap bekerja. Pada nisbah konsentrasi 1:2, komponen utama ekstrak $P$. aduncum kemungkinan dapat menyebabkan penghambatan maksimal terhadap aktivitas enzim PSMO sehingga senyawa aktif $T$. vogelii dapat terhindar dari penguraian oleh enzim tersebut dan dapat tetap bekerja menyerang bagian sasaran.

Wulan (2008) melaporkan bahwa ekstrak daun $T$. vogelii memiliki efek racun perut dan sedikit efek kontak terhadap larva $C$. pavonana. Daun $T$. vogelii mengandung senyawa aktif yang termasuk dalam golongan rotenoid, seperti rotenon, tefrosin dan deguelin (Delfel et al., 1970). Rotenon bekerja lambat dalam membunuh 
serangga tetapi dapat menyebabkan serangga segera berhenti makan. Alat mulut serangga kadang-kadang menjadi lumpuh sehingga serangga berhenti makan dan mati kelaparan. Rotenon bekerja sebagai racun respirasi sel, yaitu menghambat transfer elektron dalam NADHkoenzim ubikuinon reduktase (kompleks I) pada sistem transpor elektron di dalam mitokondria. Terhambatnya proses respirasi sel akan menurunkan produksi ATP yang merupakan sumber energi, sehingga aktivitas sel akan terganggu dan serangga menjadi lumpuh dan mati (Hollingworth, 2001).

Semua perlakuan ekstrak, baik ekstrak tunggal maupun ekstrak campuran, tidak fitotoksik pada potongan batang padi yang digunakan untuk perlakuan. Hal ini tecermin dari tidak adanya perbedaan warna maupun perubahan bentuk antara potongan batang padi kontrol dan potongan batang yang diberi perlakuan. Dengan memerhatikan keefektifan terhadap serangga uji dan ketiadaan efek fitotoksik terhadap batang padi, dapat dikemukakan bahwa ekstrak $P$. aduncum dan $T$. vogelii memiliki potensi yang baik sebagai insektisida nabati terhadap PBPK.

Aplikasi ekstrak $P$. aduncum dan $T$. vogelii atau campurannya terhadap PBPK di lapangan dapat dilakukan dengan memerhatikan daur hidup dan perilaku serangga tersebut. Aplikasi insektisida nabati tersebut dapat dilakukan sesaat setelah telur menetas menjadi larva instar 1 . Pada masa tersebut larva diharapkan akan memakan bagian daun, tulang daun dan sebagian batang yang sudah terkena insektisida nabati. Namun insektisida nabati ini masih memiliki keterbatasan di antaranya belum diketahui potensi efek sistemiknya pada tanaman padi sehingga belum diketahui dengan pasti apakah dapat mengendalikan larva PBPK yang terdapat di dalam batang padi.

\section{SIMPULAN DAN SARAN}

Campuran ekstrak buah $P$. aduncum dan daun $T$. vogelii pada nisbah konsentrasi 1:1, 2:1, dan 1:2 lebih beracun daripada ekstrak tunggalnya dan bersifat sinergis terhadap larva penggerek batang padi kuning $S$. incertulas. Urutan toksisitas campuran ekstrak tersebut pada taraf LC50 dari yang paling beracun terhadap larva $S$. incertulas ialah campuran ekstrak dengan nisbah 1:2, 2:1, dan 1:1. Selain efektif terhadap serangga uji, campuran ekstrak $P$. aduncum dan $T$. vogelii tidak fitotoksik terhadap batang padi yang digunakan dalam pengujian. Dengan demikian, campuran ekstrak tersebut, khususnya dengan nisbah konsentrasi 1:2, berpotensi untuk digunakan sebagai alternatif pengendalian terhadap larva $S$. incertulas.

\section{DAFTAR PUSTAKA}

Abizar M, dan D Prijono. 2010. Aktivitas insektisida ekstrak daun dan biji Tephrosia vogelii J.D. Hooker (Leguminosae) dan ekstrak buah Piper cubeba L. (Piperaceae) terhadap larva Crocidolomia pavonana (F.) (Lepidoptera: Crambidae). JHPT Trop. 10:112.

[BB Padi]. Balai Besar Penelitian Tanaman Padi. 2012. Pengendalian hama penggerek batang padi. [Online]. Balai Besar Padi, Subang. http://bbpadi.litbang.deptan.go.id/index.ph $\mathrm{p} /$ in/berita/hasil-hasil-penelitian/ 510 perpenggerek-batang (Diakses 26 November 2012).

Bernard CB, HG Krishnamurty, D Chauret, T Durst, BJR Philogene, P Sanchez-Vindas, C Hasbun, L Poveda, LS Roman, and JT Arnason. 1995. Insecticidal defenses of Piperaceae from the Neotropics. I Chem Ecol. 21(6):801-814.

[BPS] Badan Pusat Statistik. 2014. Laju pertumbuhan penduduk menurut provinsi. [Online]. BPS, Jakarta. http://bps.go.id/tab_sub/view.php? tabel=1\&daftar $=1 \&$ id subyek=12\&notab=2 (Diakses 5 Maret 2014).

Chou TC and P Talalay. 1984. Quantitative analysis of dose-effect relationships: the combined effects of multiple drugs or enzyme inhibitors. Adv. Enz. Regl. 22:2755.

Dadang dan D Prijono. 2008. Insektisida Nabati: Prinsip, Pemanfaatan, dan Pengembangan. Departemen Proteksi Tanaman, Institut Pertanian Bogor, Bogor.

Delfel NE, WH Tallent, DG Carlson, and IA Wolff. 1970. Distribution of rotenone and deguelin in Tephrosia vogelii and separation of rotenoid-rich fractions. J. Agric. Food Chem. 18:385-390.

Direktorat Perlindungan Tanaman Pangan. 2013. Luas serangan organisme pengganggu tumbuhan (OPT) utama pada tanaman padi tahun 2011 dan tahun 2012. Laporan Akuntabilitas Instansi Pemerintah. 
Direktorat Perlindungan Tanaman Pangan, Kementerian Pertanian, Jakarta..

[FAO] Food and Agriculture Organization of The United Nations. 2013. Food supply quantity. [Online]. FAO, Roma. http://faostat.fao.org/site/609/ default.aspx\# ancor. (Diakses 21 Maret 2013).

Gisi U. 1996. Synergistic interaction of fungicides in mixtures. Phytopathology 86:1273-1279.

Hasyim DM. 2011. Potensi buah sirih hutan (Piper aduncum) sebagai insektisida botani terhadap larva Crocidolomia pavonana. Tesis. Institut Pertanian Bogor, Bogor.

Hollingworth RM. 2001. Inhibitors and uncouplers of mitrochondrial oxidative phosphorylation. Pp. 1169-1227 in Handbook of Pesticide Toxicology. $2^{\text {nd }}$ ed. Vol 2: Agents (Krieger R, Ed.). Academic Press, San Diego.

LeOra Software. 1987. POLO-PC User's Guide. Petaluma (US): LeOraSoftware

Metcalf RL. 1967. Mode of action of insecticide synergists. Annu. Rev. Entomol. 12:229256.

Nailufar N. 2011. Aktivitas insektisida ekstrak daun Tephrosia vogelii (Leguminosae) dan buah Piper aduncum (Piperaceae) terhadap larva Crocidolomia pavonana. Skripsi. Institut Pertanian Bogor, Bogor.

Pathak, MD and ZR Khan. 1994. Insect Pests of Rice. International Rice Research Institute, Los Baňos.

Perry, AS, I Yamamoto, I Ishaaya, and RY Perry. 1998. Insecticides in Agriculture and Environment: Retrospects and Prospects. Springer-Verlag, Berlin.

Prakash, A and J. Rao. 1997. Botanical Pesticides in Agriculture. CRC Press, Boca Raton.

Scott IM, HR Jensen, BJR Philogene, and JT Arnason JT. 2008. Piper spp. (Piperaceae) phytochemistry, insecticidal activity and mode of action. Phytochem Rev. 7:65-75.

Syahroni, YY dan D Prijono, 2013. Aktivitas insektisida campuran ekstrak buah Piper aduncum (Piperaceae) dan Sapindus rarak (Sapindaceae) terhadap larva Crocidolomia pavonana. J. Entomol. Indones. 10:39-50.

Wulan RDR. 2008. Aktivitas insektisida ekstrak daun Tephrosia vogelii Hook. F. (Leguminosae) terhadap larva Croccidolomia pavonana (F.) (Lepidoptera: Pyralidae). Skripsi. Institut Pertanian Bogor, Bogor. 